\title{
REVIEW
}

\section{Spectrum of mutations in fucosidosis}

\author{
Patrick J Willems ${ }^{1}$, Hee-Chan Seo ${ }^{4}$, Paul Coucke ${ }^{1}$, R ossana Tonlorenzi $^{3}$ and \\ John S O 'Brien² \\ ${ }^{1} D$ epartment of M edical $G$ enetics, U niversity of A ntwerp, A ntwerp, B elgium \\ ${ }^{2} \mathrm{D}$ epartment of N eurosciences and Center for M olecular Genetics, University of California at San Diego, L a Jolla, \\ USA \\ ${ }^{3}$ D epartment of Pediatrics, I stituto G iannina G aslini, G enova, Italy \\ ${ }^{4} \mathrm{D}$ epartment of M olecular B iology, U niversity of B ergen, B ergen, N orway
}

\begin{abstract}
Fucosidosis is a lysosomal storage disorder characterised by progressive psychomotor deterioration, angiokeratoma and growth retardation. It is due to deficient $\alpha$-l-fucosidase activity leading to accumulation of fucose-containing glycolipids and glycoproteins in various tissues. Fucosidosis is extremely rare with less than 100 patients reported worldwide, although the disease occurs at a higher rate in Italy, in the $\mathrm{H}$ ispanic-A merican population of $\mathrm{New}$ $M$ exico and Colorado, and in $\mathrm{Cuba}$. We present here a review study of the mutational spectrum of fucosidosis. Exon by exon mutation analysis of FUCA1, the structural gene of $\alpha-I$-fucosidase, has identified the mutation(s) in nearly all fucosidosis patients investigated. The spectrum of the 22 mutations detected to date includes four missense mutations, 17 nonsense mutations consisting of seven stop codon mutations, six small deletions, two large deletions, one duplication, one small insertion and one splice site mutation. A II these mutations lead to nearly absent enzymatic activity and severely reduced cross-reacting immunomaterial. The observed clinical variability is, therefore, not due to the nature of the fucosidosis mutation, but to secondary unknown factors.
\end{abstract}

Keywords: fucosidosis; fucosidase; lysosomal storage disorder; mutations; polymorphisms

\section{Introduction}

Fucosidosis is due to deficient activity of a lysosomal enzyme, $\alpha$-I-fucosidase (E.C. 3.2.1.51). ${ }^{1}$ When fucosidase activity is deficient, fucose is not hydrolysed from fucose-containing glycoconjugates leading to accumulation of fucosyl-glycolipids, glycopeptids and oligosaccharides in various tissues. The clinical picture mainly consists of neurodegeneration with progressive mental and motor deterioration. Additional features are angiokeratoma corporis diffusum, dysostosis multi-

Correspondence: Paul Coucke, Department of Medical Genetics, U niversity of A ntwerp, U niversiteitsplein, 1 Building T, 6th floor, B-2610 A ntwerp, Belgium. Tel: 323 8202570; Fax: 323 8202566; E-mail: coucke@uia.ua.ac.be R eceived 25 J une 1998; revised 15 September 1998; accepted 28 September 1998 plex, visceromegaly, ocular abnormalities, hearing loss, seizures, coarse features, recurrent infections, spasticity, contractures, growth retardation, muscle wasting and dystrophy. ${ }^{2-4} \mathrm{~A}$ II these clinical abnormalities are progressive, leading to cachexia and early death. A Ithough clinical heterogeneity with a very rapidly progressive course and death in infancy (type I), and a slightly milder variant with death in adulthood (type II) has been described, further studies have shown that fucosidosis has a wide continuous clinical spectrum without any evidence for real clinical heterogeneity. ${ }^{4}$

In a clinical review study compiling information from the literature and from an international questionnaire survey in North A merica, Western E urope, Japan and A ustralia, 77 patients affected with fucosidosis from 54 sibships have been reviewed. ${ }^{4} \mathrm{~A}$ few additional patients 
have been reported after 1990, but in total less than 100 fucosidosis patients have been identified, indicating that the incidence of fucosidosis must be very low. The ethnic origin of fucosidosis has a worldwide distribution and fucosidosis patients have been reported in more than 20 different countries from Europe, North and South A merica, A sia and A frica. All fucosidosis patients have nearly absent $\alpha$-l-fucosidase enzyme activity. ${ }^{5,6}$ In this molecular review study we present the spectrum of mutations in FUCA 1 responsible for polymorphisms and fucosidosis.

\section{FUCA1 Gene}

\section{cDNA Sequence}

The compiled CDNA sequence of FUCA 1 consists of 2053 base pairs. ${ }^{7,8}$ This includes $5^{\prime}$ untranslated sequences, an open reading frame of $1383 \mathrm{bp}$, a consensus polyadenylation signal AATAAA and $a$ poly $(A)^{+}$tail. The open reading frame encodes for a signal peptide of 22 amino acids and a mature protein of 439 amino acids, with a calculated molecular weight of 51338 .

The canine $\alpha$-l-fucosidase CDNA encodes for a mature protein of 465 amino acids, and has an overall similarity with the human fucosidase of $84 \% .^{9}$

\section{Genomic Structure}

FUCA 1 is composed of eight exons spanning approximately $23 \mathrm{~kb}$. The sizes of the different exons are $>374$ bp (exon 1), $135 \mathrm{bp}$ (exon 2), $138 \mathrm{bp}$ (exon 3), $106 \mathrm{bp}$ (exon 4), $201 \mathrm{bp}$ (exon 5), $191 \mathrm{bp}$ (exon 6), $100 \mathrm{bp}$ (exon 7) and $>772 \mathrm{bp}$ (exon 8), respectively. ${ }^{10}$ The canine FUCA 1 gene consists of 8 exons spanning approximately $12 \mathrm{~kb}$, with a genomic structure which is similar to that of the human gene. ${ }^{9}$

\section{FUCA1P Gene}

A sequence on chromosome 2 with homology to the structural fucosidase gene FUCA 1 has been identified by Southern blot analysis of somatic cell hybrids with FUCA 1 CDNA. It is $80 \%$ identical to the FUCA 1 CDNA, but does not have an open reading frame and does not encode fucosidase enzyme activity, indicating that it is a processed pseudogene of FUCA $1 .{ }^{10}$ It was therefore designated FUCA IP. The FU CA IP gene has been sublocalised to chromosome 2q31-q32 by FISH, in close proximity to the COL $3 A 1$ gene. ${ }^{11}$

\section{Fucosidosis Mutations}

The characterisation of the genomic structure of FUCA 1 with all its exon-intron boundary sequences ${ }^{10}$ facilitated the mutational analysis in fucosidosis patients. PCR amplification of the eight different FUCA 1 exons followed by direct sequencing or SSCP/ sequencing resulted in the identification of the majority of fucosidosis mutations including point mutations, deletions of 1 to $10 \mathrm{bp}$, and insertions of 1 to $66 \mathrm{bp}$ (Table 1). Only four (18\%) of the 22 mutations are missense mutations, whereas the remaining $18(72 \%)$ are inactivating mutations consisting of seven nonsense mutations, six small deletions, two large deletions, one small insertion, one duplication of $66 \mathrm{bp}$, and one splice site mutation (Table1). The mutations are spread throughout the open reading frame of FUCA 1 without hot spots (Figure 1). O nly one fucosidosis mutation in a total of 40 patients has not yet been identified, indicating that fucosidosis is genetically homogeneous and due to mutations in only one gene. Furthermore, fucosidosis mutations nearly always disrupt the open reading frame and not the regulatory region of FUCA 1 . A II these mutations including the missense mutations result in nearly absent $\alpha$-l-fucosidase enzymatic activity and severely deficient cross-reacting immunomaterial (CRIM ), indicating that the mutant fucosidase proteins are unstable and degrade rapidly. ${ }^{5,6}$ All but two mutations were found in homozygous form, confirming the very high rate of consanguinity found in fucosidosis families. ${ }^{4}$ The different mutations are discussed below. The patients' initials refer to the appendix table in the review study by Willems et al. ${ }^{4}$

\section{Missense Mutations}

Only four missense mutations have been identified. These include the G60D, the S63L, the N $329 Y$ and the P5R mutations described below.

\section{G60D Mutation}

The substitution of the neutral glycine residue by the acidic aspartic acid at amino acid position 60 in exon 1 $\left({ }^{179} \mathrm{G} \rightarrow \mathrm{A}\right)$ is present in homozygous forms in a large French-A merican (Cajun) family with three affected patients, $S B / C B / R L$, and in three Italian families, $A M$, $M Z / G Z$ and $S D$. The ancestors of $S D$ and $M Z / G Z$ originate from the same village of Formia (Lazio), whereas A M originates from the nearby Forio (C ampania), suggesting a common ancestor. However, an 
Table 1 Spectrum of FU CA 1 mutations in fucosidosis

\begin{tabular}{|c|c|c|c|c|c|c|}
\hline M utation & $\begin{array}{l}\text { Nucleotide } \\
\text { change }\end{array}$ & Type & $\begin{array}{l}\text { Exon/ } \\
\text { Intron }\end{array}$ & Patients & E thnic origin & References \\
\hline$P 5 R$ & ${ }^{14} \mathrm{C} \rightarrow \mathrm{G}$ & missense & exon 1 & $\mathrm{M} \circ \mathrm{A}(47)^{\mathrm{a}}$ & Sudanese $^{b}$ & 6 \\
\hline G 60D & ${ }^{179} \mathrm{G} \rightarrow \mathrm{A}$ & missense & exon 1 & $\begin{array}{l}\text { SB } / C B / R L(19) \\
A M(10) \\
M Z / G Z(3) \\
S D(2)\end{array}$ & $\begin{array}{l}\text { French-A merican } \\
\text { Italian (C ampania) } \\
\text { Italian (L azio) } \\
\text { Italian (L azio) }\end{array}$ & 16 \\
\hline S63L & ${ }^{188} \mathrm{C} \rightarrow \mathrm{T}$ & missense & exon 1 & $\mathrm{FX}(13)$ & I talian (Veneto) & 32 \\
\hline Q 77X & ${ }^{229} \mathrm{C} \rightarrow \mathrm{T}$ & stop codon & exon 1 & $\begin{array}{l}\text { G M /R M (1) } \\
\mathrm{A} \mathrm{gC} \mathrm{(14)}\end{array}$ & $\begin{array}{l}\text { Italian (Campania) } \\
\text { Italian (Campania) }\end{array}$ & $\begin{array}{l}17,33 \\
17\end{array}$ \\
\hline E 113fs & 340del10 & deletion & exon 1 & MB & A ustrian & 6 \\
\hline P141fs & 421delC & deletion C & exon 2 & $\begin{array}{l}\text { M S/SS/C (4) } \\
\text { SI } \\
\text { R Z/A Z (8) } \\
\text { R obF /R osF }\end{array}$ & $\begin{array}{l}\text { Italian (Calabria) } \\
\text { Italian (Calabria) } \\
\text { Italian (C alabria) } \\
\text { Italian (Calabria) }\end{array}$ & 33 \\
\hline K 151fs & 451delA A & deletion A A & exon 2 & $\mathrm{CS}(12)$ & Italian (Puglia) & 16 \\
\hline W 183X & ${ }^{549} \mathrm{G} \rightarrow \mathrm{A}$ & stop codon & exon 3 & M M & A ustrian & 6 \\
\hline Y $211 X$ & ${ }^{633} \mathrm{C} \rightarrow \mathrm{A}$ & stop codon & exon 3 & $\mathrm{M} \mathrm{B}(25)$ & B elgian & 33 \\
\hline S216fs & 646delA & deletion $\mathrm{A}$ & exon 3 & $\begin{array}{l}\mathrm{EN}(40) \\
\mathrm{GH}\end{array}$ & $\begin{array}{l}\text { Canadian-Indian } \\
\text { B ritish }\end{array}$ & 6,33 \\
\hline E 253fs & 758delA & deletion A & exon 5 & $C(49)$ & Turkish & 34 \\
\hline S265fs & $\begin{array}{l}\text { 794delC } \\
{ }_{954+1} \mathrm{G} \rightarrow \mathrm{A}\end{array}$ & $\begin{array}{l}\text { deletion C } \\
\text { splice site }\end{array}$ & $\begin{array}{l}\text { exon } 5 \\
\text { intron } 5\end{array}$ & $\begin{array}{l}\text { GD }(20) \\
\text { SB }\end{array}$ & $\begin{array}{l}\text { Portuguese } \\
\text { E ast Indian-Zambian }\end{array}$ & $\begin{array}{l}33 \\
35\end{array}$ \\
\hline N $329 Y$ & ${ }^{985} \mathrm{~A} \rightarrow \mathrm{T}$ & missense & exon 6 & GS & A ustrian & 6 \\
\hline Y 330fs & $\begin{array}{l}\text { 1988insT } \\
\text { 1030ins66 }\end{array}$ & $\begin{array}{l}\text { insertion T } \\
\text { duplication }\end{array}$ & $\begin{array}{l}\text { exon } 6 \\
\text { exon } 6\end{array}$ & $\begin{array}{l}\mathrm{M} \circ \mathrm{A}(47) \\
\mathrm{JH}(44)\end{array}$ & Sudanese $^{b}$ & $\begin{array}{l}6 \\
36\end{array}$ \\
\hline E 375X & ${ }^{1123} \mathrm{G} \rightarrow \mathrm{T}$ & stop codon & exon 6 & $\begin{array}{l}J T(31) \\
L A(32) \\
J C / F C(38) \\
B L(39) \\
F V(34) \\
J G / G G(33)\end{array}$ & H ispanic-A merican & 16,37 \\
\hline W 382X & ${ }^{1145} \mathrm{G} \rightarrow \mathrm{A}$ & stop codon & exon 6 & $\begin{array}{l}\text { CS }(12) \\
\text { TB }\end{array}$ & $\begin{array}{l}\text { Italian (Puglia) } \\
\text { Italian (Puglia) }\end{array}$ & 33 \\
\hline G 401X & ${ }^{1201} \mathrm{G} \rightarrow \mathrm{T}$ & stop codon & exon 7 & $\begin{array}{l}\text { A B } \\
\text { SW }\end{array}$ & $\begin{array}{l}\text { G erman (Volga) } \\
\text { G erman }\end{array}$ & 38,39 \\
\hline G ross deletion & & deletion & exons 7-8 & FZ/SZ(48) & A Igerian & 4,16 \\
\hline Q 422X & ${ }^{1264} \mathrm{C} \rightarrow \mathrm{T}$ & stop codon & exon 8 & $\begin{array}{l}\mathrm{LS}(9) \\
\mathrm{DeG} / \mathrm{DaG}(45) \\
\mathrm{RP} / \mathrm{L} P(46) \\
\mathrm{DM} / \mathrm{SM}(18) \\
\mathrm{GM} / \mathrm{R} \mathrm{M}(1) \\
\mathrm{CM}\end{array}$ & $\begin{array}{l}\text { Italian (U mbria) } \\
\text { Cuban } \\
\text { Cuban } \\
\text { French } \\
\text { Italian (Sicilia) } \\
\text { French/Scottish }\end{array}$ & $12,39,40$ \\
\hline G ross deletion & & deletion & exon 4 & $\begin{array}{l}\text { JDH (26) } \\
\text { CN (27) }\end{array}$ & Dutch & $\begin{array}{l}\text { Coucke and Willems, } \\
\text { unpubl, result. (1996) } \\
\text { Seo and O 'B rien, } \\
\text { unpubl, result. (1996) }\end{array}$ \\
\hline
\end{tabular}

2The numbers after the patients' initials represent the numbering system in the clinical review study by Willems et al ${ }^{5}$;

${ }^{\mathrm{b}}$ The P5R and Y 330fs mutations are present in the same patient.

obvious common ancestor of the Cajun family, SB/CB/ $R L$, has not been identified.

\section{S63L Mutation}

The substitution of serine by leucine at amino acid position 63 in exon $1\left({ }^{188} \mathrm{C} \rightarrow \mathrm{T}\right)$ has only been identified in a single patient from the Veneto region in Northern Italy. Diminished in vitro expression of mutant $\alpha$-I-fucosidase proved that the S63L mutation was the disease-causing mutation.

\section{N329Y Mutation}

This missense mutation in exon $6\left({ }^{985} \mathrm{~A} \rightarrow \mathrm{T}\right)$ replacing the conserved asparagine residue at amino acid position 329 by a larger and hydrophobic amino acid, 
Table 2 Polymorphisms in FUCA 1 and fucosidase-related genes

\begin{tabular}{|c|c|c|}
\hline G ene & $\begin{array}{l}\text { Chromosomal } \\
\text { localisation }\end{array}$ & Polymorphism \\
\hline FUCA 1 structural gene & 1 & Pvull RFLP \\
\hline FUCA 1 structural gene & 1 & Bgll RFLP \\
\hline FUCA 1 structural gene & 1 & $\begin{array}{l}\text { electrophoretic } \\
\text { protein } \\
\text { polymorphism }\end{array}$ \\
\hline FUCA IP pseudogene & 2 & $\begin{array}{l}\text { low or high } \\
\text { intracellular } \\
\text { activity }\end{array}$ \\
\hline regulating gene $\mathrm{a}^{\mathrm{a}}$ & 1 & Bcll RFLP \\
\hline FUCA 2 regulating gene ${ }^{a}$ & 6 & $\begin{array}{l}\text { low or high } \\
\text { plasma activity }\end{array}$ \\
\hline
\end{tabular}

${ }^{\mathrm{a}} \mathrm{G}$ enes for which there is no formal proof of existence

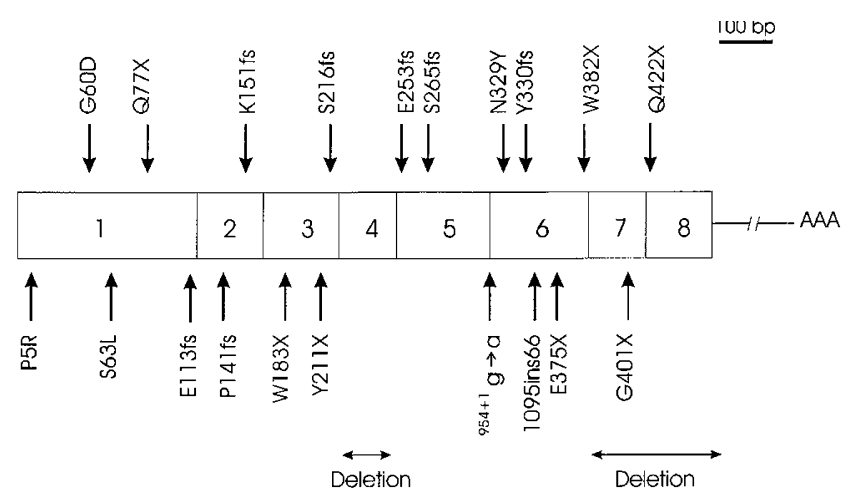

Figure 1 Schematic representation of FU CA 1 mutations in fucosidosis. The cDNA structure representing the different exons is shown with the different FU CA 1 mutations.

tyrosine, was found in homozygous form in an A ustrian patient.

\section{P5R Mutation}

This mutation was found in a single Sudanese patient. The substitution of proline by arginine at amino acid position 5 in exon 1 might cause a conformational change in the secondary structure of the $\alpha$-I-fucosidase leader peptide. A Ithough the P5R mutation was found in homozygous form in one patient it is not certain that the P5R mutation causes the disease, as the patient also has a Y 330fs mutation in homozygous form. As the Y 330fs mutation results in a truncated fucosidase protein which is probably unstable, this mutation alone probably leads to fucosidosis. Therefore, the significance of the P5R mutation is not clear, and it rather represents a polymorphism than a disease-causing mutation.

\section{Inactivating Mutations}

E ighteen inactivating mutations described below have been identified in fucosidosis.

\section{Q77X Mutation}

This stop codon mutation in exon $1\left({ }^{229} \mathrm{C} \rightarrow \mathrm{T}\right)$ is present in homozygous form in an Italian patient $\mathrm{A} \mathrm{gC}$ and in heterozygous form in the siblings $G M / R M$. The parents of $A g C$ and the mother of $G M / R M$ are from $N$ apoli (Campania), which suggests they are related.

\section{E113fs Mutation}

A deletion of $10 \mathrm{bp}$ in exon 1 (340del10) causing a frameshift and a premature stop codon has been found in an A ustrian patient.

\section{P141fs Mutation}

A deletion of a single $C$ at nucleotide position in 421 (421delC) in exon 2 causing a frameshift and a premature stop codon has been identified in three I talian families, A Z/RZ , SS/M S/patient C, and SI from Calabria. The siblings $A Z$ and $R Z$ belong to the same pedigree as RobF and RosF, the initial fucosidosis patients described by Durand et al. ${ }^{2}$ Patient SS, who had similar clinical and pathological abnormalities as $D$ urand's original family, was the first patient in whom an $\alpha$-l-fucosidase deficiency was demonstrated. ${ }^{1} \mathrm{~A}$ Iso MS and patient $C$ belong to this fucosidosis family. $L$ arge pedigrees of both Calabrian families have been published. ${ }^{4}$ The two families and patient SI have not yet been linked by pedigree analysis, but the fact that they are from nearby villages in southern Calabria, suggests that they are all related and descendants from a common ancestor carrying the P141fs mutation. The relatively high consanguinity of $\mathrm{Calabrian}$ families is, therefore, the most likely explanation for the high frequency of fucosidosis in Calabria.

\section{K151fs Mutation}

A deletion of 2 bp A A in exon 2 (451delA A) giving rise to a frameshift has been found in heterozygous form in an I talian patient, CS, from the Puglia region, who is also heterozygous for the W $382 X$ mutation.

\section{W183X Mutation}

This stop codon mutation in exon $3\left({ }^{549} \mathrm{G} \rightarrow \mathrm{A}\right)$ was found in homozygous form in an Austrian patient.

\section{Y211X}

This stop codon mutation in exon $3\left({ }^{633} \mathrm{C} \rightarrow \mathrm{A}\right)$ was identified in homozygous form in a Belgian patient, MB. 


\section{S216fs}

A deletion of a single $A$ in exon 3 (646delA ) was found in $E N$, in which the second mutation has not yet been found. $\mathrm{EN}$ has a native Indian mother, whereas his father is Irish. As the S216fs is also present in homozygous form in a B ritish patient, G H , EN and G H might be related.

\section{E253fs Mutation}

$A$ deletion of a single $A$ in exon 5 (758delA) was found in homozygous state in a Turkish patient, $\mathrm{Ce}$.

\section{S265fs Mutation}

A deletion of a single $C$ in exon 5 (794delC) was found in homozygous form in a Portugese patient, GD.

\section{Splice Site Mutation}

$A$ homozygous $G \rightarrow A$ point mutation of the first nucleotide of the $5^{\prime}$ splice site of intron $5\left({ }^{954+1} G \rightarrow A\right.$ ) was found in an E ast Indian-Zambian patient, SB. The consequence of this splice site mutation on the protein is unknown.

\section{Y330fs Mutation}

A homozygous insertion of $T$ in exon 6 (988insT) was found in a patient that was also homozygous for the P5R mutation (see above).

\section{A 66 bp Duplication}

A $n$ in-frame $66 \mathrm{bp}$ duplication of nucleotides 1030 to 1095 (1030ins66) of exon 6 was identified in homozygous form in patient $\mathrm{JH}$.

\section{E375X Mutation}

The stop codon mutation E 375X $\left({ }^{1123} \mathrm{G} \rightarrow \mathrm{T}\right)$ in exon 6 has been found in homozygous form in six $\mathrm{H}$ ispanicA merican families from $\mathrm{N}$ ew $\mathrm{M}$ exico and Colorado. A s the families have the same fucosidosis mutation and the same $\mathrm{H}$ ispanic background, and the population is known to be highly consanguineous, it is likely that they are all descendants from a common ancestor carrying the $\mathrm{E} 375 \mathrm{X}$ mutation.

\section{W382X Mutation}

This stop codon mutation in exon $6\left({ }^{1145} \mathrm{G} \rightarrow A\right)$ is present in heterozygous form in CS and in homozygous form in TB, two Italian patients originating from the Puglia region, suggesting that they are related.

\section{G401X Mutation}

The $G 401 X$ mutation creates a premature stop codon in exon $7\left({ }^{1201} \mathrm{G} \rightarrow \mathrm{T}\right)$ and was found in two patients, $A B$ and SW. Patient AB originates from the former G erman Volga R epublic in R ussia, whereas patient SW lives near Würzberg in Germany. Both patients have consanguineous parents but pedigree analysis could not indicate a relation between the two families. Nevertheless, it is likely that they have a common ancestor carrying the G401X mutation as this has never been found in other patients.

\section{Q422X Mutation}

This stop codon mutation in exon $8\left({ }^{1264} \mathrm{C} \rightarrow \mathrm{T}\right)$ was the first mutation found in fucosidosis patients. The Q $422 \mathrm{X}$ mutation has now been identified in six different families, including $L S$ from the $U$ mbria region (I taly), GM/RM from Sicily (Italy), DeG/DaG and RP/LP from Cuba, D M/SM from France, and CM , a Canadian patient with mixed Scottish/French origin. More than 10 fucosidosis patients from the same province in $\mathrm{Cuba}$ (Holguin), have been found to carry the Q422X mutation in homozygous state, which makes it very likely that they have a common ancestor (Coucke and Willems, unpublished observations). It is unclear whether all patients with the Q422X mutation have a common ancestor in view of their different ethnic origin, although the $\mathrm{Q} 422 \mathrm{X}$ mutation is present on the same haplotype background for 2 RFLPs (Pvull and Bgll ).

\section{Deletion of Exon 4}

In two D utch patients, J dH and $\mathrm{CN}$, a deletion of exon 4 and its flanking intronic sequences was found in homozygous form suggesting that they are probably related.

\section{Deletion of Exons 7 and 8}

A homozygous deletion of exons 7 and 8 was detected in A Igerian siblings, $\mathrm{FZ/SZ}$.

\section{Polymorphisms}

\section{Restriction Fragment Length Polymorphisms (RFLPS) in FUCA1}

$B$ oth a Pvull and a Bgll RFLP have been identified in FUCA 1. Pvull identifies a two-allele $R F L P^{13}$ with bands at either $7.0 \mathrm{~kb}(70 \%)$ or $6.0 \mathrm{~kb}(30 \%)$. B gll identifies a two-allele polymorphism with either one band at $12 \mathrm{~kb}$ or two bands at $6.5 \mathrm{~kb}(63 \%)$ and $5.5 \mathrm{~kb}$ $(37 \%)$.

A $n$ additional $B$ cll R FLP can be detected by FU CA 1 CD NA probes. This RFLP, however, it not located in 
FUCA 1 , but in the fucosidase pseudogene FU CA 1P on chromosome $2 .^{14}$

\section{Electrophoretic Polymorphism in FUCA1}

A common fucosidase enzyme polymorphism can be detected in blood and tissues by starch gel electrophoresis and isoelectric focusing. ${ }^{15}$ I soenzymes with the Fu1 phenotype have a more acidic pl than Fu2 isoenzymes. A llele frequencies of Fu1 and Fu2 are 0.72 and 0.28 , respectively, with only minor differences in allele frequency between different ethnic populations. $A{ }^{842} \mathrm{~A} \rightarrow \mathrm{G}$ missense mutation, responsible for the substitution of glutamine by arginine at amino acid position 281, has been identified in exon 5 of FUCA $1,{ }^{16-18}$ and ${ }^{281} \mathrm{Arg}$ is associated with the Fu2 phenotype of more basic isoenzymes. ${ }^{19,20}$

\section{Bcll RFLP in the Fucosidase Pseudogene FUCA1P}

A two-allele $\mathrm{BCll}$ polymorphism is present in FU CA 1P. ${ }^{14}$ The B ClI RFLP is best revealed by $\mathrm{Bcll} / \mathrm{Pst}$ double digestion, which reveals polymorphic bands of $12.0 \mathrm{~kb}$ (absence of B cll site) and $8.1 / 3.9 \mathrm{~kb}$ (presence of $B$ cll site). A llele frequencies are $0.58(12 \mathrm{~kb})$ and $0.42(8.1 \mathrm{~kb})$. The $B$ cll RFLP can also be identified by FUCA 1 CDNA probes because of the high degree of homology between FUCA IP and FUCA 1.

\section{Polymorphism in a Putative Regulatory Gene FUCT}

Variation in the pattern of intracellular $\alpha$-I-fucosidase synthesis has been reported by Tümmler et $\mathrm{al}^{21}$ who proposed to call this polymorphic regulatory gene FUCT, and suggested that FUCT mapped in close proximity to the structural fucosidase gene $F \cup C A 1$, in view of its linkage disequilibrium with FUCA 1.

DiCioccio and Brown, ${ }^{22}$ however, found no evidence for such a regulatory gene, and therefore the existence of FUCT is uncertain.

\section{Low Plasma Activity Polymorphism in FUCA2}

Some normal individuals have low plasma $\alpha$-l-fucosidase activity. This variant trait is not associated with any kind of disease and represents an autosomal recessive enzyme polymorphism. ${ }^{23,24}$ The mean allele frequencies are 0.72 and 0.28 for high and low enzyme activity, respectively. A nalogous plasma low activity polymorphisms have been described for other lysosomal enzymes such as $\alpha$-L-iduronidase, arylsulfatase A, hexosaminidase A, galactocerebrosi- dase and $\alpha$-galactosidase $A$. (For a review on low activity polymorphisms, see Thomas. ${ }^{25}$ )

The enzymatic fucosidase activity in plasma of variants is between 10 and $30 \%$ of the control mean. ${ }^{23,24,26}$ Variants have also a lower fucosidase activity in cultured fibroblasts. ${ }^{27}$ In leucocytes and lymphoblastoid cell lines, however, the fucosidase activity of variants and normals is not significantly different. ${ }^{23,24} \mathrm{~A}$ II eight FUCA 1 exons and exon-intron boundaries from individuals who were homozygous for the low activity trait, were sequenced but no mutation was found (Seo and O'B rien, unpublished results). On the other hand, weak evidence for linkage between a putative gene controlling plasma fucosidase activity, FUCA 2, and the plasminogen gene on chromosome 6 has been provided by Eiberg et al, ${ }^{28}$ but this has never been confirmed nor refuted. Therefore, the existence of FUCA 2 is uncertain.

\section{Animal Model for Fucosidosis}

Severe $\alpha$-L-fucosidase deficiency with residual enzyme activity below $5 \%$ of controls can be found in English and Australian springer spaniels derived from a few original English stud dogs. Especially in Australia the incidence of fucosidosis in these dogs is exceedingly high $(4 \%)$ causing breeding problems. Fucosidosis in springer spaniels manifests itself as a mainly neurodegenerative condition with progressive tremor, ataxia, proprioceptive defects, deafness, blindness, inability to swallow, loss of learned behaviour and wasting. This results in a lethargic state and death at the age of 3-5 years. The pathologic abnormalities are similar to those of the human condition. ${ }^{29} \mathrm{~A} 14 \mathrm{bp}$ deletion at the $3^{\prime}$ end of exon 1 of Fucal was found, resulting in a frame shift with a premature stopcodon. ${ }^{9,30}$ The affected springer spaniel dogs have been used as an animal model to treat fucosidosis in vivo with bone marrow transplants and in vitro by retrovirus mediated gene transfer. ${ }^{31}$

\section{Acknowledgements}

We are grateful to N A erts and R Bernaerts for secretarial assistance.

\section{References}

1 Van H oof F, H ers H G : M ucopolysaccharidosis by absence of $\alpha$-fucosidase. $L$ ancet 1968; 1: 1198. 
2 D urand P, Borrone C, D ella Cella G: A new mucopolysaccharide lipid storage disease? Lancet 1966; 2: 1313-1314.

3 Loeb H, Tondeur M, Jonniaux G, M ockel-Pöhl S, Vamos Hurwitz E : Biochemical and ultrastructural studies in a case of mucopolysaccharidosis " $F$ ". Fucosidosis. Helv Paediatr A cta 1969; 5: 519-537.

4 Willems PJ, G atti R, D arby JK et al: Fucosidosis revisited: A review of 77 patients. Am J Med Genet 1991; 38: 111-131.

5 Willems PJ, D arby JK, D iCioccio R A et al: Identification of a mutation in the structural $\alpha$ - $L$-fucosidase gene in fucosidosis. A m J H um G enet 1988; 43: 756-763.

6 Cragg $\mathrm{H}$, Williamson $M$, Young $E$ et al: Fucosidosis: genetic and biochemical analysis of eight cases. J Med G enet 1997; 34: 105-110.

7 Fukushima $\mathrm{H}$, deW et J $\mathrm{R}$, O 'B rien J S: M olecular cloning of a CDNA for human $\alpha$-L -fucosidase. Proc $N$ atl A cad Sci USA 1985; 82: 1262-1265.

8 Occhiodoro T, Beckmann KR, Morris P, Hopwood JJ: $H$ uman $\alpha$ - $L$-fucosidase: complete coding sequence from cDNA clones. Biochem Biophys Res Commun 1989; 64: 439-445.

9 Skelly BJ, Sargan Dr, Herrtage ME, Winchester BG: The molecular defect underlying canine fucosidosis. J Med G enet 1996; 33: 284-288.

10 Kretz KA, Cripe D, Carson GS, Fukushima $H$, O'B rien J S: Structure and sequence of the human $\alpha$ - $L$-fucosidase gene and pseudogene. Genomics 1992; 12: 276-280.

11 Coucke P, M angelschots K, Speleman F et al: A ssignment of the fucosidase pseudogene FU CA IP to chromosome region 2q31 $\rightarrow$ q32. Cytogenet Cell Genet 1991; 57: $120-122$.

$12 \mathrm{~K}$ retz KA, D arby J K, Willems PJ, O 'B rien J S: Characterization of $\mathrm{ECORI}$ mutation in fucosidosis patients: a stop codon in the open reading frame. J M ol Neurosci 1989; 1 : 177-180.

13 Darby JK, Willems PJ, Nakashima $P$ et al: Restriction analysis of the structural alpha-L-fucosidase gene and its linkage to fucosidosis. Am J Hum Genet 1988; 43: 749-755.

14 Willems PJ, Carritt B, Coucke P, Darby JK, Van der A uwera BJ, O 'B rien J S: B Cll R FLP in fucosidase pseudogene (FU CA 1P). Nucleic A cids Res 1991; 18: 5583.

15 Turner BM, Turner VS, Beratis NG, Hirschhorn K: Polymorphism of human $\alpha$-L-fucosidase. Am J Hum G enet 1975; 27: 651-661.

16 Seo HC, Willems PJ, K retz KA, M artin BM, O 'Brien J S: Fucosidosis: four new mutations and a new polymorphism. H um Mol G enet 1993; 2: 423-429.

$17 \mathrm{Y}$ ang $\mathrm{M}$, A llen $\mathrm{H}$, DiCioccio RA : Pedigree analysis of $\alpha$ - $L$-fucosidase gene mutations in a fucosidosis family. Biochim Biophys A cta 1993; 1182: 245-249.

18 Y ang M, DiCioccio R A : A G In-281 to A rg substitution in $\alpha$ - $L$-fucosidase is responsible for a common polymorphism detected by isoelectric focusing. H um G enet 1994; 93: $597-599$

19 Yang $M$, Allen SH, Fukushima H, DiCioccio RA: A missense mutation $\left({ }^{197} G \rightarrow A\right.$ ) in the $\alpha$ - $L$-fucosidase gene of fucosidosis patients leads to loss of $\alpha$ - $L$-fucosidase. Glycosyl D is 1994; 1: 15-19.
20 Cragg $H$, Winchester B, Seo HC, O'B rien J, Swallow D: $\mathrm{M}$ olecular basis of the common electrophoretic polymorphism (Fu1/Fu2) in human $\alpha$-L -fucosidase. J M ed Genet 1994; 31: 659-660.

21 Tümmler B, D uthie M, Bricald M, Riordan J R: A gene regulating the time dependence of $\alpha$ - $L$-fucosidase concentration is closely linked with the structural gene in man. H um G enet 1984; 67: 396-399.

22 DiCioccio RA, Brown K S: B iosynthesis, processing, and extracellular release of $\alpha$-L-fucosidase in lymphoid cell lines of different genetic origins. B iochem $G$ enet 1988; 26: 401-420.

23 Wood S: H uman $\alpha$-L-fucosidase: a common polymorphic variant for low serum enzyme activity, studies of serum and leukocyte enzyme. H um H ered 1979; 29: 226-229.

24 Willems PJ, Romeo E, Den Tandt WR, Van EIsen A F, Leroy J G : pH-dependent association-dissociation of high and low activity plasma alpha-L-fucosidase. $\mathrm{H}$ um $\mathrm{G}$ enet 1981; 59: 115-118.

25 Thomas GH: "Pseudodeficiencies" of lysosomal hydrolases. A m J H um G enet 1994; 54: 934-940.

26 G atti R, Cavalieri S, Romeo G: Relationship between alpha-L-fucosidase deficiency in plasma and alphaL-fucosidase activity in leukocytes. H um G enet 1979; 48: 23-30.

27 Van Elsen AF, Leroy JG, Wauters JG, Willems PJ, Buytaert $\mathrm{C}$, Verheyen $\mathrm{K}$ : In vitro expression of alphafucosidase activity polymorphism observed in plasma. H um G enet 1983; 64: 235-239.

28 Eiberg H, Mohr J, Nielsen LS: Linkage of plasma $\alpha$-L-fucosidase (FUCA 2) and the plasminogen (PLG) system. Clin G enet 1984; 26: 23-29.

29 A braham D, Blakemore W F, D ell A et al: The enzymatic defect and storage products in canine fucosidosis. B iochem J 1984; 222: 25-33.

30 Occhiodoro T, A nson DS: I solation of the canine alpha$L$-fucosidase CDNA and definition of the fucosidosis mutation in English Springer Spaniels. Mamm Genome 1996; 7: 271-274.

31 Occhiodoro T, Hopwood J, Morris CP, A nson DS: Correction of alpha- $L$-fucosidase deficiency in fucosidosis fibroblasts by retroviral vector-mediated gene transfer. H um G ene Ther 1992; 3: 365-369.

32 Seo HC, Yang M, Tonlorenzi $\mathrm{R}$ et al: A missense mutation (S63L) in $\alpha$ - $L$-fucosidase is responsible for fucosidosis in an Italian patient. H um M ol G enet 1994; 3: 2065-2066.

33 Seo HC, Willems PJ, O 'Brien J S: Six additional mutations in fucosidosis: three nonsense mutations and three frameshift mutations. H um M ol G enet 1993; 2: 1205-1208.

34 Seo HC, Kunze J, Willems PJ, Kim A H, Hanefield F, $O$ 'B rien J S: A single-base deletion mutation in a Turkish patient with fucosidosis. H um Mutation 1994; 3: 407-408.

35 Williamson $M$, Cragg H, Grant J et al: A 5 ' splice site mutation in fucosidosis. J M ed G enet 1993; 30: 218-223.

36 Seo HC, Yang M, K im A H, O'Brien J S, DiCioccio RA, Gordon BA: A 66 base pair insertion in exon 6 of the $\alpha$ - $L$-fucosidase gene of a fucosidosis patient. $\mathrm{H}$ um M utat 1996; 7: 183.

$37 \mathrm{Y}$ ang $\mathrm{M}, \mathrm{A}$ llen $\mathrm{H}, \mathrm{D}$ iCioccio $\mathrm{RA}$ : A mutation generating a stop codon in the $\alpha$ - $L$-fucosidase gene of a fucosidosis patient. Biochem Biophys Res Commun 1992; 189: 1063-1068. 
38 Seo HC, Heidemann PH, Lutz E, O'B rien: A nonsense mutation in two German patients with fucosidosis. H um Mutat 1995; 6: 184-185.

39 Willems PJ, Garcia CA, De Smedt MCH: Intrafamilial variability in fucosidosis. Clin Genet 1988; 34: 7-14.
40 Gordon BA, Gordon KE, Seo HC, Yang M, DiCioccio RA, O'Brien J S: Fucosidosis - with dystonia. Neuropediatrics 1995; 26: 325-327. 